\title{
Human onchocerciasis in Brazil: an overview
}

\author{
Oncocercose humana no Brasil: uma revisão
}

Anthony J. Shelley 1

\footnotetext{
1 Department of Entomology, Biomedical Sciences Theme, The Natural History Museum. Cromwell Road London, SW7 5BD, UK t.shelley@nhm.ac.uk
}

\begin{abstract}
Human onchocerciasis was recently discovered in Brazil among Yanomámi Indians living along the border region with Venezuela in the States of Amazonas and Roraima. The article reports on the history of the disease's discovery, its distribution, and incrimination of vector simuliid species. The literature that has been generated on the parasite, its vectors, and control of the disease is critically analyzed as well as the organization of epidemiological surveys and the control program developed by the Brazilian government and an international agency. Suggestions for future work are made.
\end{abstract}

Key words Onchocerciasis; Filariasis; Simuliidae; Yanomámi Indians; South American Indians

Resumo A oncocercose humana foi descoberta recentemente no Brasil entre os índios Yanomámi que vivem ao longo da fronteira com a Venezuela nos Estados do Amazonas e Roraima. O autor faz uma revisão da história da descoberta da doença, sua distribuição e a identificação de diferentes espécies de simulídeos vetores. Analisam-se a literatura sobre o parasita, seus vetores e o controle da doença, assim como, a organização de inquéritos epidemiológicos e do programa de controle desenvolvido pelo governo brasileiro junto com uma agência internacional. O autor conclui com sugestões para atividades futuras na área.

Palavras-chave Oncocercose; Filariose; Simuliidae; Yanomámi; Índios Sul-Americanos 


\section{Introduction}

Despite the discovery of a focus of human onchocerciasis in the Brazilian Amazon 35 years ago, the epidemiology of the disease is still not fully understood, largely as a result of the high cost of research in Amazonia and the relatively low public health importance of the disease in Brazil as a whole. The objectives of this overview are to introduce the reader to the literature by way of review papers, highlight some of the past and present problem areas, and suggest topics for future research.

\section{The disease and its distribution}

The presence of human onchocerciasis in Brazil was first recorded by Bearzoti et al. (1967), who removed two nodules containing Onchocerca volvulus from the head of a North American missionary child living in the Yanomámi Indian area in northern Brazil. Subsequent studies in the 1970s largely by Moraes and co-workers based at the Evandro Chagas Institute in Belém, Brazil, and by Rassi (a short-term consultant to the Pan-American Health Organization) defined the limits of the focus (Figure 1) as almost coinciding with the area occupied by Amerindians, principally of the Yanomámi tribe (Figure 2). Members of this tribe live in one of the most isolated areas of Brazil (Figure 3) and until recently had little contact with the rest of the country. Moraes and his team went on to show that prevalence rates of the disease were higher in the more mountainous regions along the border with Venezuela than in the lower-lying areas on the periphery of the focus, that skin microfilarial densities were higher below the waist as in West Africa than above the waist as in Guatemala and Mexico, and that visual acuity was affected by the parasite. Prospection of simuliids and incrimination of vectors were carried out by Shelley and co-workers at Brasília University and later in the Oswaldo Cruz Institute. These pioneering studies were hampered by the extreme isolation of the onchocerciasis focus and hence difficulty of access. Only in villages in which missionaries or FUNAI (National Indian Foundation) staff had constructed airstrips and had made initial contacts with the Indians could surveys be made. Overviews of these earlier studies in Brazil may be found in: Moraes (1991), Moraes et al. (1979), and Shelley et al. (1997) and in the Venezuelan part of the Amazonia focus (Figure 1), which has similar characteristics, in Yarzábal et al. (1985). The original parasitological and entomological re- search that defined the extent of the Amazonia focus, parasite prevalence rates, and incriminated vectors was followed by a period when other more important diseases in Brazil were the priority areas for a Department dealing with vector-borne diseases (formerly SUCAM, now FUNASA) in the Ministry of Health. Nevertheless, considerable logistical support was provided by the FUNASA, CNPq (National Council for Scientific and Technological Development), and international organizations for basic biosystematic research on the previously poorly studied Simuliidae in Brazil, particularly following the discovery of a new focus of the disease at Minaçu outside Amazonia (Figure 1). In 1993 the FUNASA set up an onchocerciasis control program in the Amazonia focus in Brazil as part of a multinational control effort for Latin America involving countries affected by the disease (Brazil, Colombia, Ecuador, Guatemala, Mexico, Venezuela). It was coordinated and partially funded by the Onchocerciasis Elimination Program for the Americas (OEPA), a regional coalition of representatives from the health ministries of these countries, various international banks, United Nations agencies, and the Centers for Disease Control and Prevention (CDC) and Carter Center in the United States. The current situation (based on this program) in the Brazilian part of the Amazonia focus is as follows: about 9,500 Indians (mainly Yanoma$\mathrm{mi}$ ) live in an area of about $200,000 \mathrm{~km}^{2}$ and over 1,100 (about $30 \%$ ) of almost 4,000 tested from 1993-1996 were positive for onchocerciasis (Coelho et al., 1998; Py-Daniel, 1997 - differences exist in the data cited in these two papers, but the infection levels are approximately in agreement). Hyperendemicity continues to be associated with the mountainous center of the focus, while the periphery is hypoendemic or free of the disease, a stratification even more clearly seen from recent data for Venezuela (Vivas-Martínez et al., 1998). Surveys of parasite prevalence rates still continue as ivermectin is progressively applied as a control measure. The major questions currently asked are whether the disease has worsened in terms of prevalence and intensity and whether control using ivermectin is working. Both are difficult to answer for different reasons. An accurate comparison between the two surveys (Moraes in the 1970s and FUNASA from 1993 on) is not possible because different sampling methods were used, and the original survey by Moraes was far less extensive due to access problems. Assessment of the control program's efficacy is more complex because treatment was started in most localities before baseline data on Annual Trans- 
mission Potentials (ATPs) of vector species had been obtained. More recent research in Venezuela (Vivas-Martínez et al., 2000a, 2000b) has assessed the parasite prevalence and intensity in relation to age and sex in areas of different endemicity. These findings were then related to rapid epidemiological assessment methods (REA) and strategies for ivermectin distribution.

Another important area that has received limited attention because of funding constraints is the potential dispersal of onchocerciasis from the Amazonia focus to non-endemic regions of Brazil. In the first review of work in the Brazilian part of the Amazonia focus, Moraes et al. (1979) alerted the health authorities to its potential dispersal to circumjacent areas by infected Indians leaving the focus by the newly constructed Northern Perimeter Road or to other parts of Brazil by tin and gold miners who had recently entered the focus. Unless large numbers of highly infected Indians were to migrate to the savannas to the east of the focus, the first alternative for dispersal was judged to be unlikely due to the poor vectorial competence of the three local anthropophilic simuliid species (subject reviewed in Shelley et al., 1997). However, an autochthonous case of onchocerciasis was reported in 1986 some 2,000 $\mathrm{km}$ South of the Amazonia focus at Minaçu in Goiás State and is believed to have been acquired as a result of the arrival in the 1970s of gold miners previously infected with the disease in the Amazonia focus (Figure 1). MaiaHerzog et al. (1999) found evidence for a focus of the disease in this area based on a serodiagnostic (ELISA) test. A proportion of the individuals tested, none of whom had ever visited the Amazonia focus, was seropositive for O. volvulus and hence had had contact with the disease. Skin biopsies from the majority of a small sample of seropositive cases yielded no living parasites but were found to contain parasite DNA and also gave a positive Mazzotti reaction. From these preliminary data, no firm conclusion may be made on whether transmission had already ceased in the area or whether the focus is still active. Although the human immune response to $O$. volvulus probably lasts for several years, DNA from damaged parasites in skin biopsies is probably only detectable by PCR for several weeks, so that low-level infections are thought to currently occur. It has also been shown that the four anthropophilic simuliid species in the Minaçu focus (S. auripellitum, $S$. guianense s.l., S. minusculum, S. nigrimanum) (Figures 4, 5, 6, 7) are all capable of transmitting O. volvulus (Shelley et al., 2001b). Despite these findings, several health administrators and re-
Distribution of human onchocerciasis and mansonelliasis in Brazil.

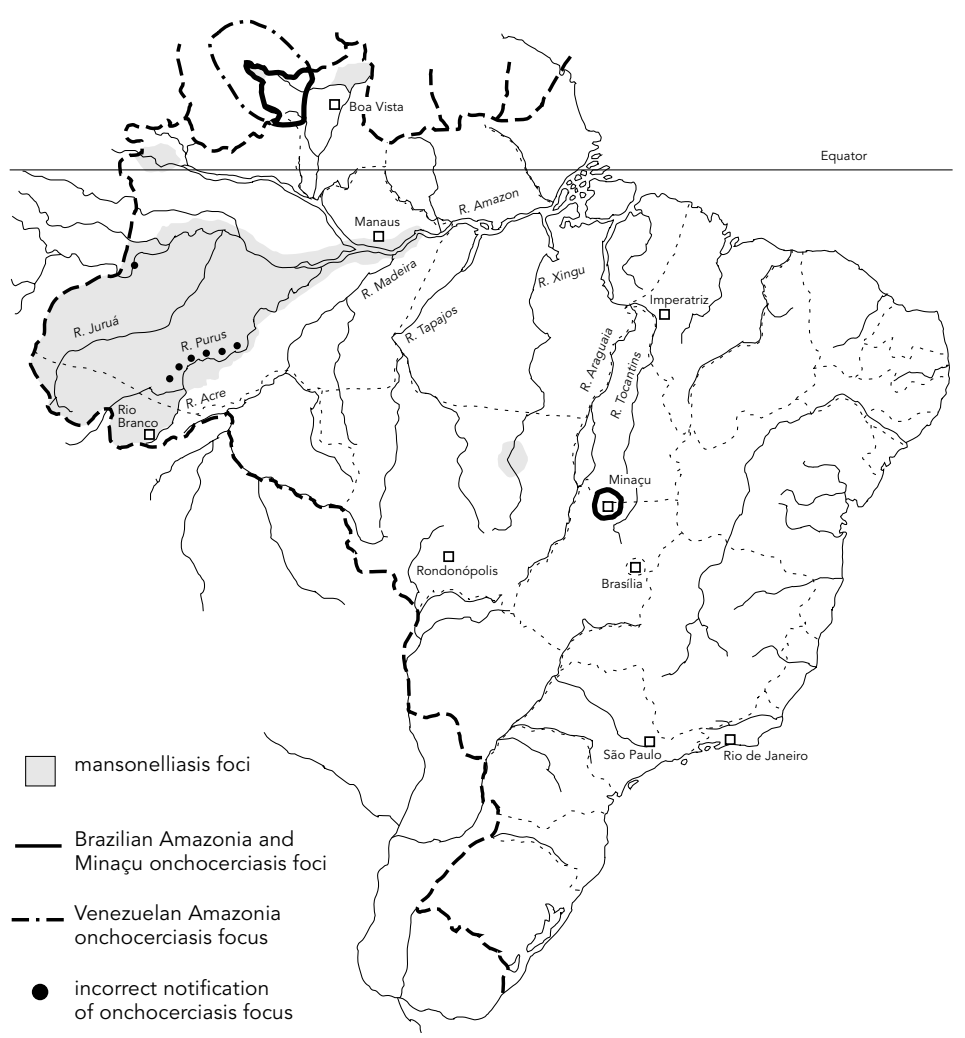

Figure 2

Yanomámi Indians in area of $O$. volvulus transmission.

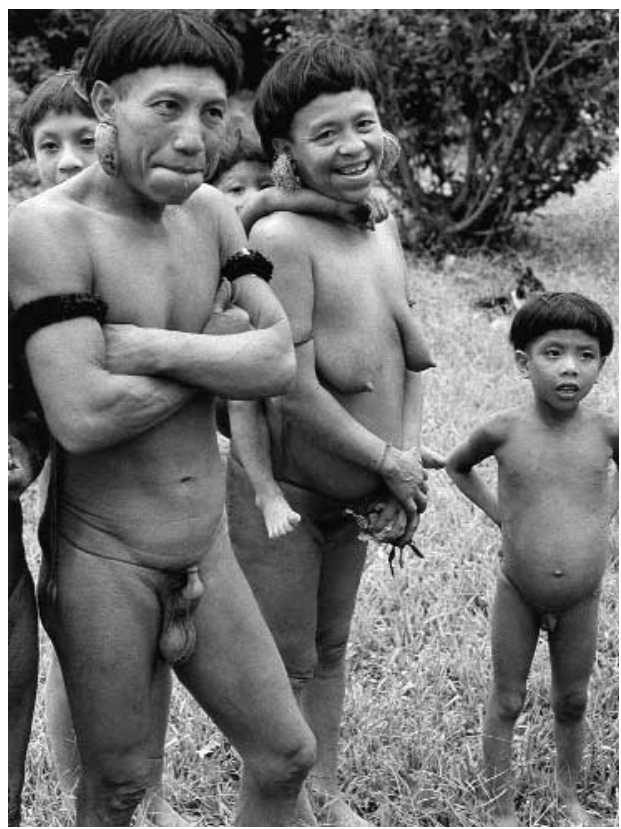


Figure 3

Isolated maloca (communal hut) of Yanomámi Indians in area

of onchocerciasis transmission.

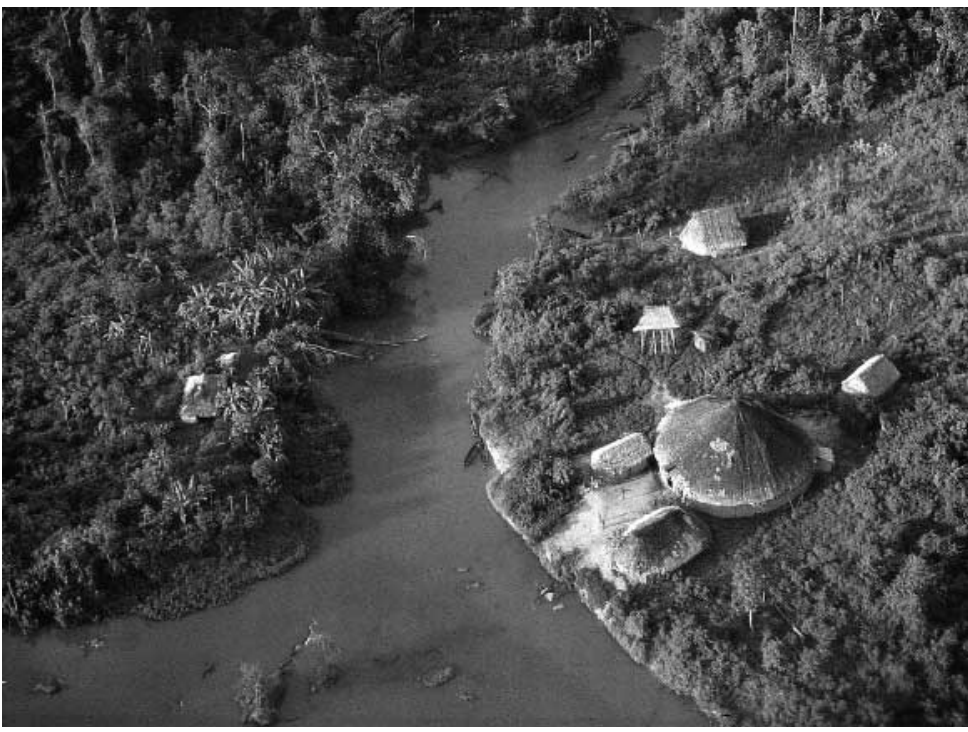

Figure 4

Distribution of S. guianense s.I., primary vector.

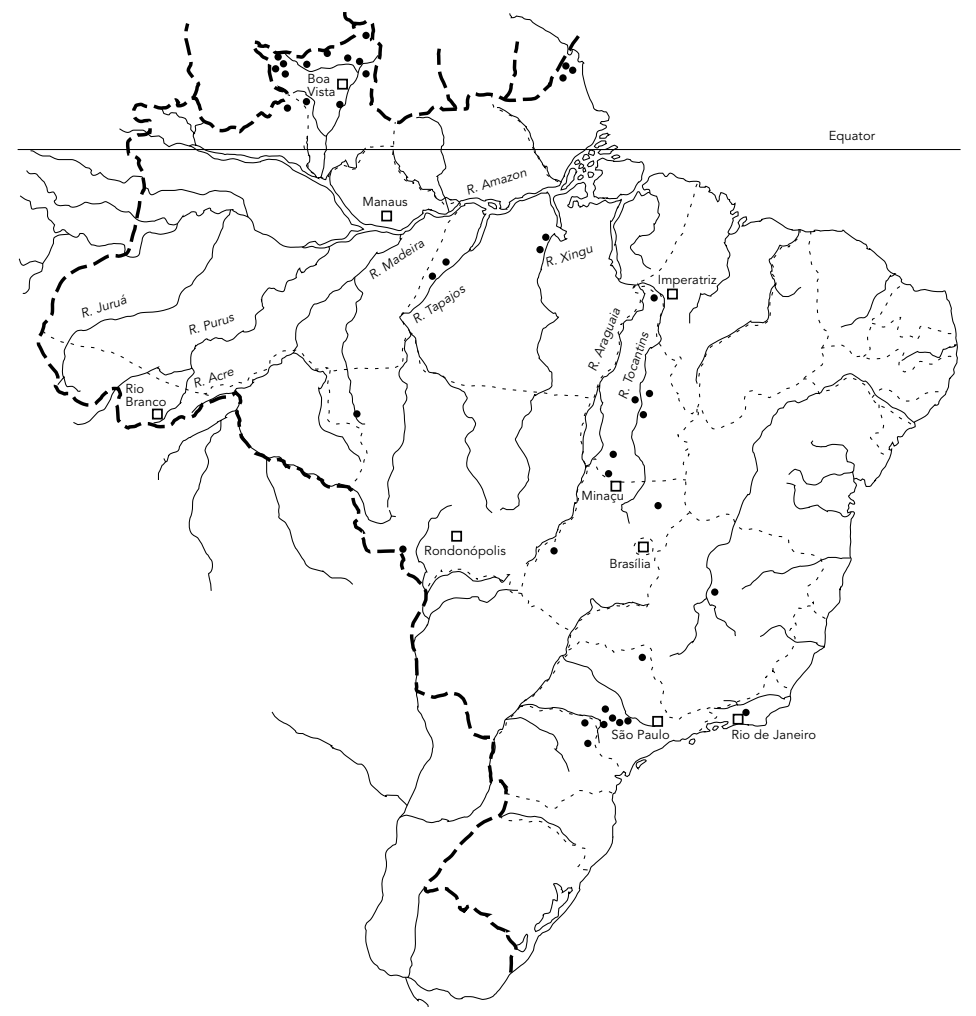

searchers associated with OEPA were unconvinced by the evidence for this focus because of the lack of visual evidence of live microfilariae and went even further to state that "The hypothesis that human migration in and out of endemic areas may result in the emergence of new foci in the Americas remains unproven and unlikely" (Richards et al., 2000). In response to this misleading article, Maia-Herzog et al. (2000) corrected the factual errors, clarified that human migration is the most probable reason for the disease reaching the Americas from Africa and for its dispersal in the Americas and is a concern of the World Health Organization (WHO) in Africa in terms of recrudescence of the disease in cleared areas. The methods used at Minaçu are considered by WHO to be more sensitive than classical parasitological methods. Despite warnings 20 years ago (Moraes et al., 1979), subsequent reference to the dangers of human migration and the widespread distribution of potential and known vectors in Brazil (Py-Daniel, 1997; Shelley et al., 1997), and evidence for visitors to the Amazonia focus acquiring the disease, no support has been given by OEPA to sample the tens of thousands of gold miners who have visited the focus despite the willingness of the Brazilian military forces in the area to collaborate in such a venture (PyDaniel, 1997).

\section{The parasite}

The history of the naming of the filarial nematode O. volvulus (Leuckart, 1892) collected from a West African Negro, the synonymy of the name $O$. caecutiens originally given to this species in Central America, and evidence for its origin in Africa are covered by Crosskey (1990). Further evidence, based on the history of human migration to Latin America (Maia-Herzog, 1999) and parasite DNA in Latin America being closer to the more pathogenic savanna form of the parasite (Zimmerman et al., 1994), supports this hypothesis. However, the forest form of the parasite may also be present. All stages of the parasite have been well described, but difficulties still exist in some areas in identification of the most pathogenic and frequently encountered stage of the parasite (the microfilaria), which principally occurs in the skin. Microfilariae are identified to species by their length and width as well as the arrangement of their nuclei in relation to specific landmarks such as the cephalic space, tail space, and nerve ring. In Africa the only other skin-dwelling filaria is the morphologically characteristic Mansonella 
streptocerca, but where this occurs sympatrically with $O$. volvulus misidentification of the two species has already been recorded (Fischer et al., 1998). In Latin America M. ozzardi is a filarial species generally recorded in the peripheral blood, but which has been shown to also occur in the skin in Brazil (Moraes et al., 1983) and in other parts of Latin America. Sympatry of this parasite in the Amazonia onchocerciasis focus has already caused misidentifications and errors in O. volvulus prevalence rates. It has also been misidentified as O. volvulus in two areas where only $M$. ozzardi has been recorded (Figure 1). The first involved Ticuna Indians living alongside the Solimões river (Upper Amazon) and was based on stained microfilariae in skin biopsies (Moraes et al., 1983). The second (described in Shelley et al., 2001a) involved an ELISA, reputedly species-specific to O. volvulus, which detected a high proportion of seropositive cases among people living in communities alongside the river Purus. Subsequent morphological examination revealed that most of the microfilariae in skin biopsies were more similar to M. ozzardi than O. volvulus, but other specimens could not be identified to species. Morphometric studies (Dr. R. Post \& Ms. Z. Adams, personal communication) showed that the ratio between the length of the last nucleus to the length of the tail was significantly larger in M. ozzardi. Based on this criterion, only $M$. ozzardi was present in the area, confirmed by a study of parasite DNA by Morales-Hojas et al. (2001). The ELISA used in this study for detection of $O$. volvulus cross-reacts with M. ozzardi and hence needs to be further refined before it can be reliably used where the two parasites are sympatric, such as in the Amazonia onchocerciasis focus. Identification problems between these two filarial species also occur in the larval stages found in the vectors (see review in Shelley, 1994). Only the microfilaria and infective stages can be identified morphologically, but since at least four filarial species (of which one remains unidentified) are transmitted by simuliids in the Amazonia focus, other techniques are necessary to augment or replace this method (reviewed in Shelley et al., 1997). Examination of parasite DNA (Morales-Hojas et al., 2001) will distinguish $M$. ozzardi from $O$. volvulus but does not indicate the parasite stage. This method is the most rapid for calculation of ATPs during the onchocerciasis control program and is based on the detection of infective larvae. Consequently, simuliid heads may be tested for the presence of infective larvae, but recently ingested microfilariae would register as false positives. The
Figure 5

Distribution of S. auripellitum, potential vector.

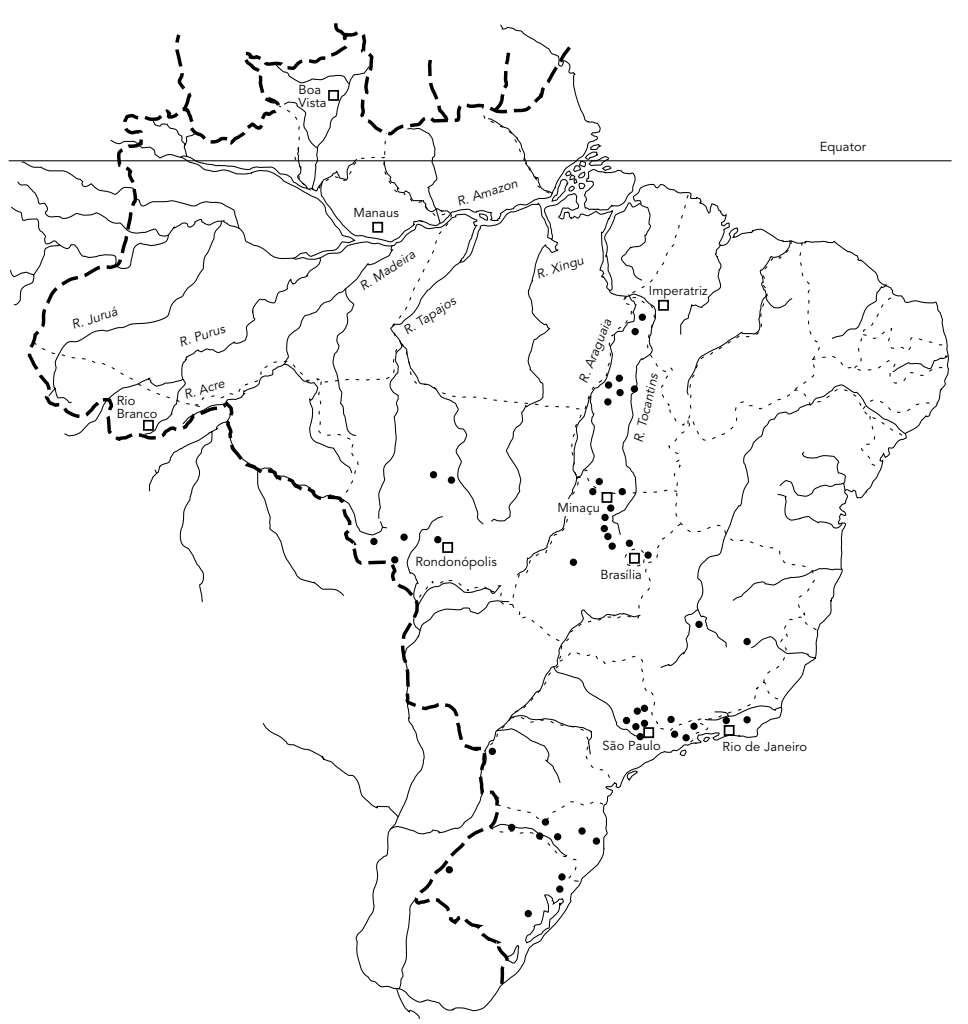

Figure 6

Distribution of S. nigrimanum, potential vector.

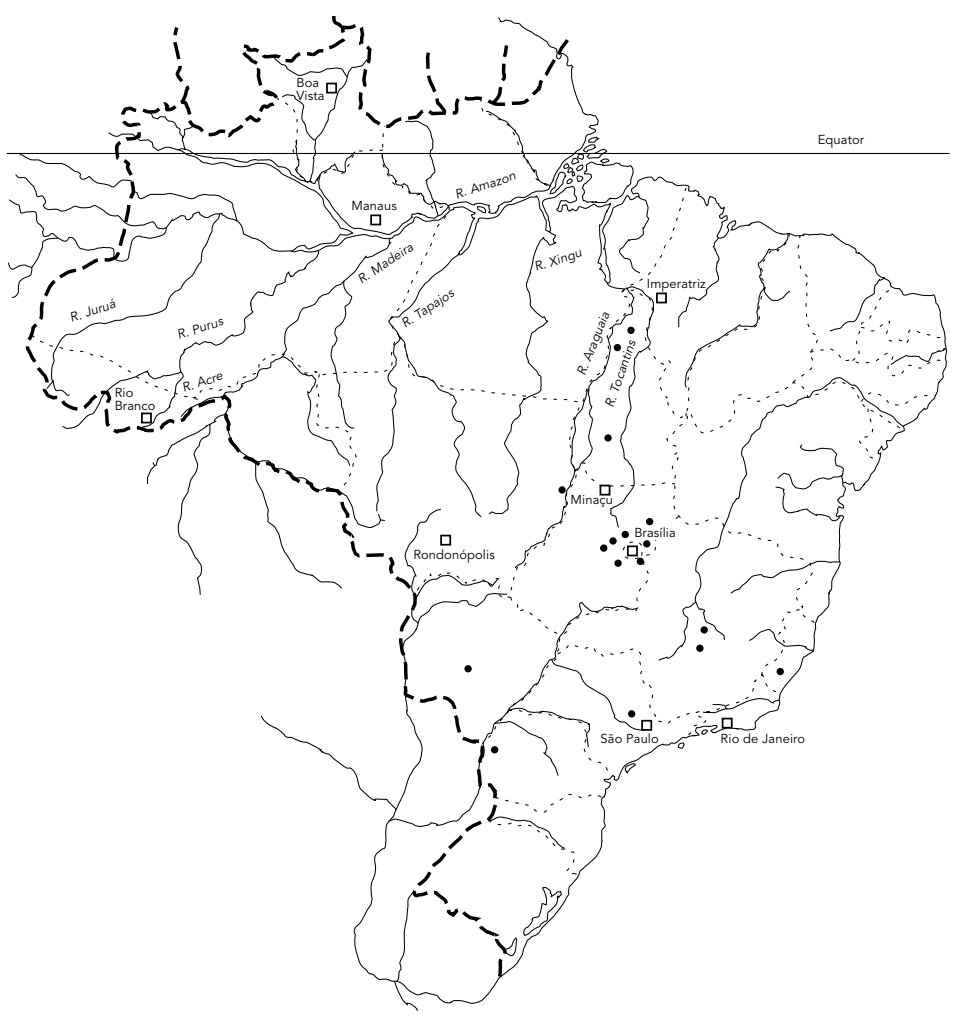


degree to which microfilariae may occur in the head of partially fed flies in landing catches is probably low (Shelley et al., 1979) but is likely to be higher in species with a cibarial armature because microfilariae become trapped on the cibarial teeth.

\section{The vectors}

Following the discovery of the Amazonia onchocerciasis focus, studies on simuliids in this previously unprospected area were carried out to establish the species present and the vectors of O. volvulus. The taxonomy of the Simuliidae in both parts of this focus at this stage was virtually unknown and independent studies in the two countries resulted in the misidentification of several previously poorly described species and the description of supposedly new species. Major overview papers are: Py-Daniel (1983), Py-Daniel \& Moreira-Sampaio (1995), Ramírez-Pérez (1983), Ramírez-Pérez et al. (1982), and Shelley et al. (1997). The simuliid fauna during the 1970s in the Brazilian part of the focus numbered 14 while in Venezuela 22

\section{Figure 7}

Distribution of S. minusculum, potential vector.

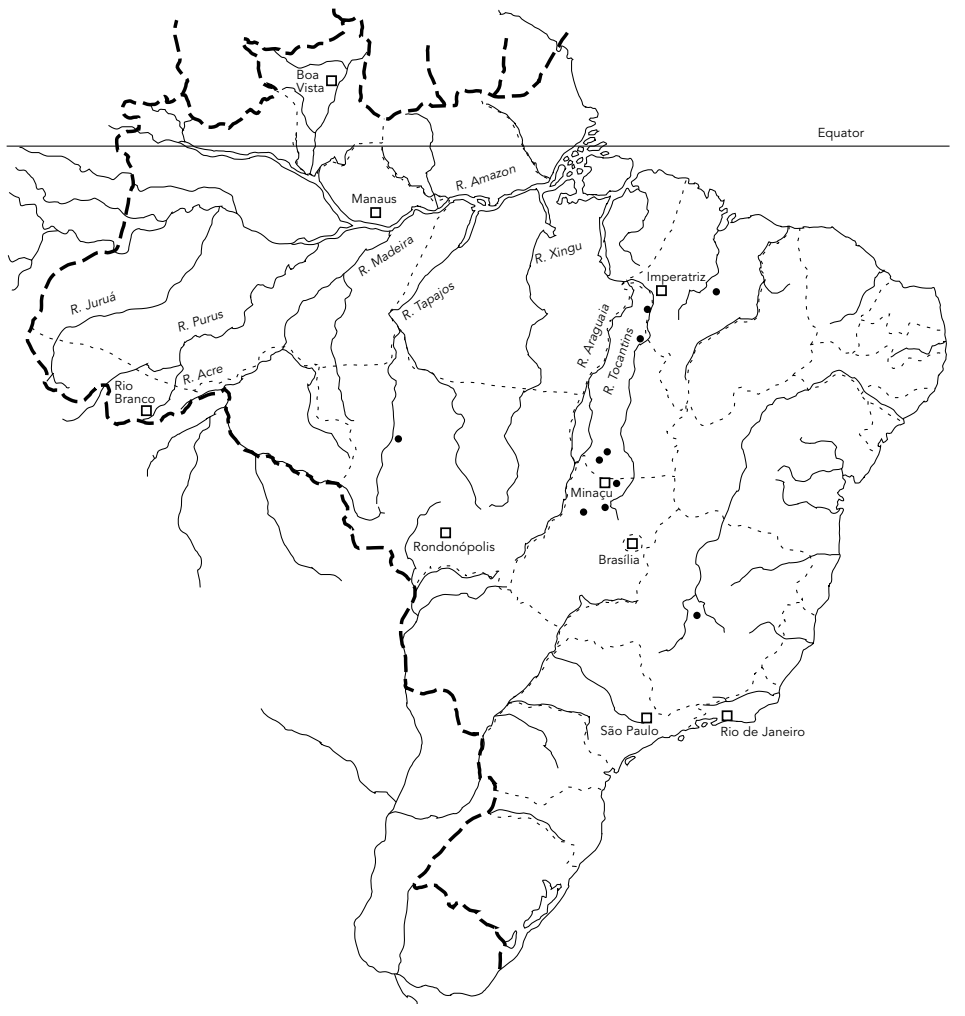

species were recorded. More recent work in Brazil (Py-Daniel, 1997) has increased the number of species to 26 , of which eight were not identified. The most problematic species in terms of morphological characters have been S. oyapockense s.l. and S. roraimense. Both species are easily and reliably separated by the male scutal pattern and gonostyles of the genitalia, but the females of both species, the stage most frequently encountered and responsible for parasite transmission, are indistinguishable. Light incidence was found to affect scutal pattern as a function of the distribution of scutal setae, so a standard method for viewing specimens had to be established before scutal patterns could be properly studied (Lowry et al., 1996). The variation noted in adult and immature flies cannot be attributed as being intraspecific or interspecific without accompanying cytological and/or molecular data, leading Shelley and co-workers to accept as an interim measure five specific names as synonyms of S. oyapockense s.l. (Shelley et al., 1997). Identification has also been complicated by the presence of complexes of sibling species in the following vector species: S. exiguum, S. guianense, and S. oyapockense (Shelley et al., 1997, 2000). Recently, variation in banding patterns of larval polytene chromosomes and DNA of populations of S. oyapockense was analyzed (Dr. S. Luz, personal communication) and the correlation between these and previous morphological variations will now facilitate a reexamination of S. oyapockense and its five synonyms.

During the 1970s studies revealed that there were four predominant anthropophilic species in the focus that transmit O. volvulus: S. guianense s.l. and S. incrustatum in highland areas and S. oyapockense s.l. and S. roraimense in lowland villages, while $S$. exiguum s.l. was a suspected vector (reviewed in Shelley et al., 1997) (Figures 4, 8, 9, 10). Although the distribution of S. guianense s.l., the most effective vector, was widespread in the focus, significant anthropophilic populations were only found at the higher altitudes where the disease was hyperendemic. Vector cytospecies determination could not be made because breeding grounds were extremely difficult to find in localities where anthropophilic populations occur. Throughout Brazil S. guianense s.l. has a wide distribution in large, sunlit rivers, but less common anthropophilic populations appear to have a more discrete distribution and in some cases are found breeding in smaller rivers. The distribution of this successful vector therefore limits the potential dispersal of onchocerciasis from the Amazonia focus. In contrast both S. oyapoc- 
kense s.l. and S. roraimense (the main lowland vectors) have wide distributions in lowland Amazonia, and S. incrustatum is a common species in highland areas of Brazil, but their possession of cibarial teeth greatly reduces their competence as vectors. More recent work embracing a larger number of collection sites (reviewed in Py-Daniel, 1997) confirmed these findings and added S. exiguum s.l. as a vector at the lowland hypoendemic locality of Ericó.

Limited studies of the biology of these four vector species were carried out in a highland and several lowland localities during the 1970s, thereby giving an indication of their seasonal biting densities, daily biting cycles, parous rates, infection rates with filarial species, and breeding grounds, and this work was reviewed in relation to similar sporadic studies in Venezuela (Shelley et al., 1997). The relevance of these data to the epidemiology and control of onchocerciasis in Brazil in relation to other foci in Latin America was discussed. Major conclusions were that the pattern of onchocerciasis endemicity is directly related to the simuliid species present. Of the numerous factors that affect onchocerciasis transmission in Latin America (reviewed by Shelley, 1994), the presence or absence of cibarial teeth and the compatibility of parasite to vector morphospecies or cytospecies have major effects on parasite transmission. The relevance of these factors to the epidemiology and control of onchocerciasis in the Americas are reviewed in Shelley $(1988,1991)$. It is clear from these reviews that the epidemiology of onchocerciasis in the diverse foci in Latin America is unique and that different combinations of control measures are indicated. Unlike the extensive endemic areas of West Africa where knowledge of the biology of a vector cytospecies in one country will apply in a neighboring country thereby permitting an overall control program, in the Americas the focal nature of the disease necessitates individual control strategies for each focus. Py-Daniel (1997) makes exactly the same point in his review of more recent work in the Brazilian focus. Although Py-Daniel and co-workers have made concentrated efforts at the hyperendemic locality of Xitei/Xideia (Andreazze \& Py-Daniel, 1999; Medeiros \& Py-Daniel, 1999; Py-Daniel, 1997) on the biology of simuliid vectors in relation to onchocerciasis transmission before ivermectin treatment began, no other detailed surveys are underway in the focus. Future research efforts should concentrate on the biology of vector morphospecies and cytospecies to better understand the epidemiology and control of the disease. More recent and detailed work
Figure 8

Distribution of S. oyapockense s.I./S. roraimense, primary vector.

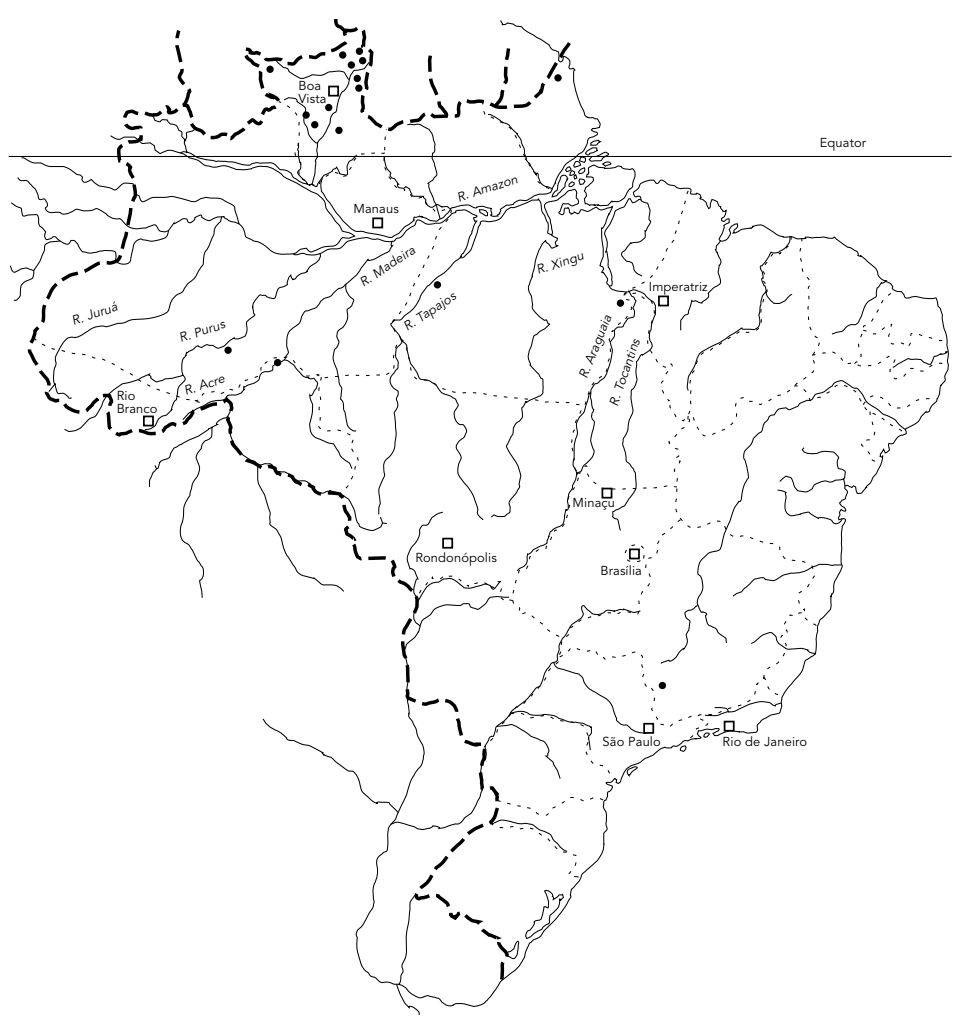

Figure 9

Distribution of S. incrustatum, secondary vector.

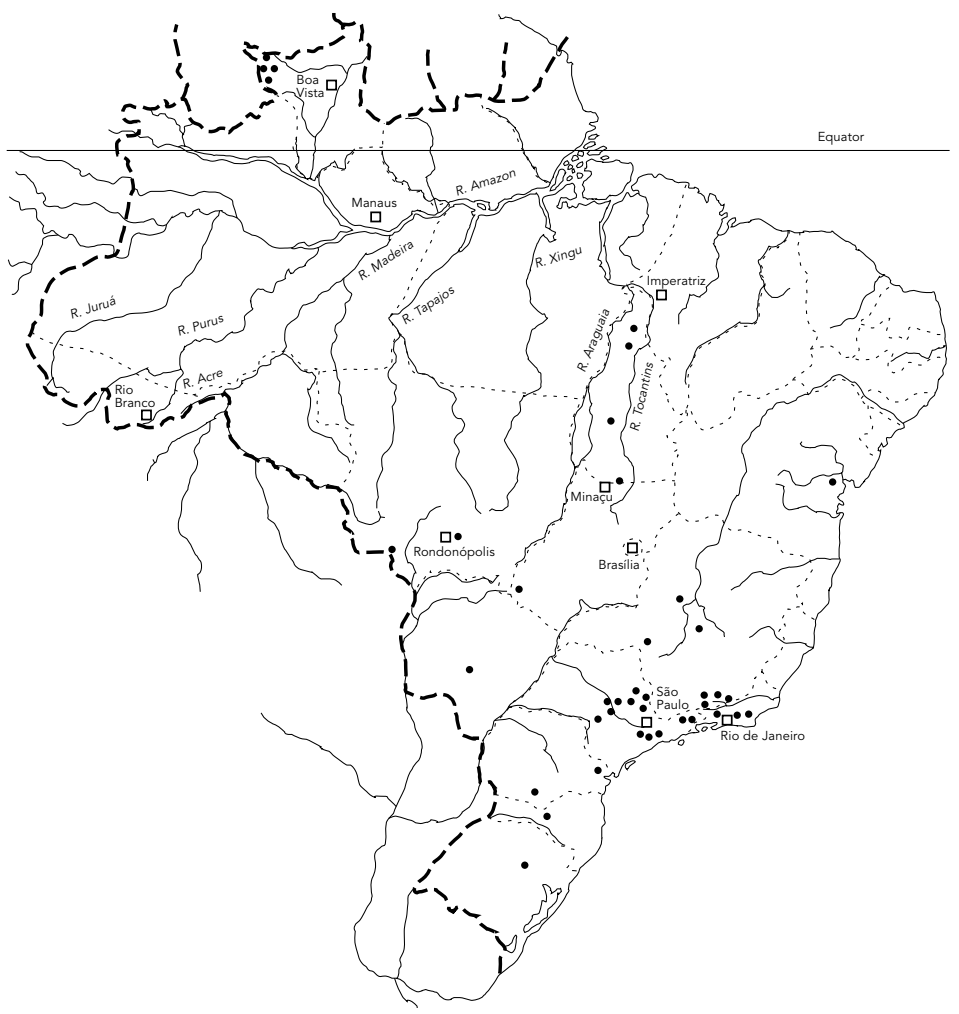


Distribution of S. exiguum s.I., secondary vector.

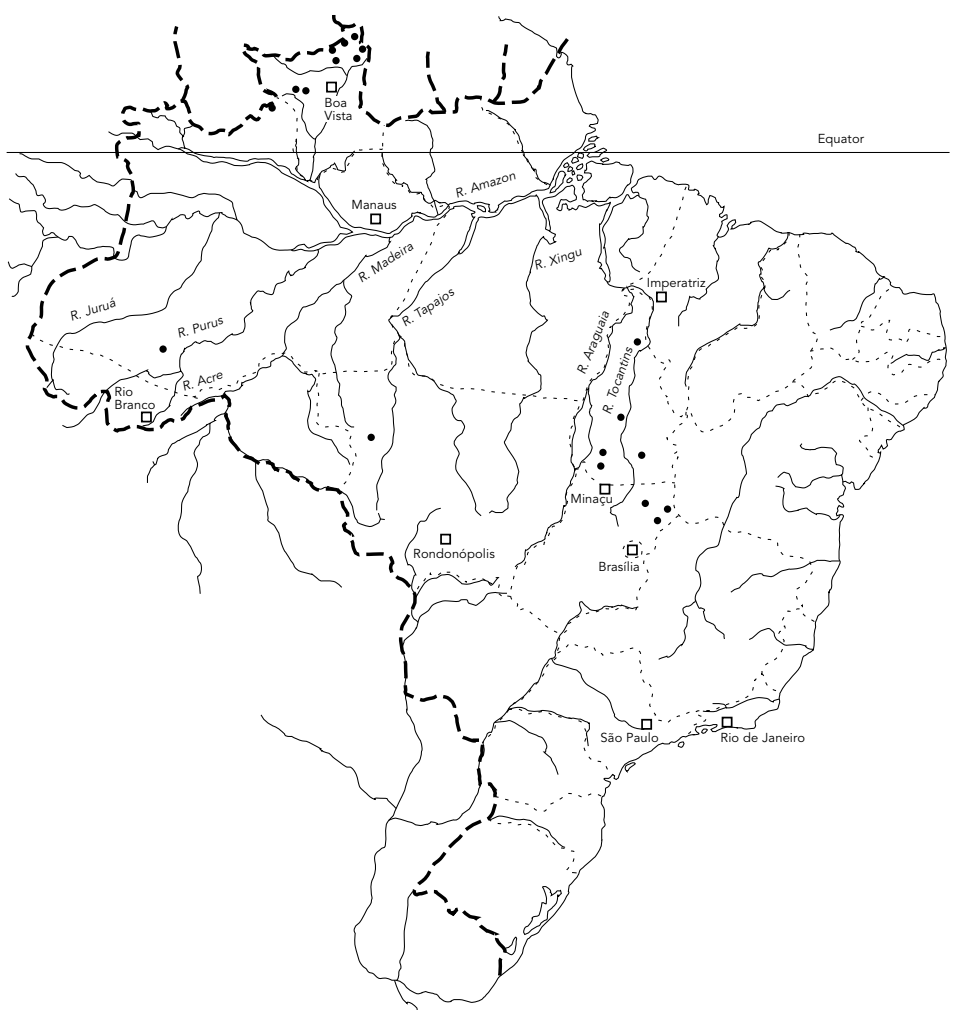

in parts of the focus in Venezuela (Grillet et al., 2001) confirmed the relationship between altitude and season with respect to vector species and provided evidence suggesting that transmission occurs more in the dry season and the transition period between seasons.

\section{Control of onchocerciasis}

Two main methods are available for controlling onchocerciasis, the killing of microfilariae and reduction of longevity of adult females of $O$. volvulus in man using ivermectin and the destruction of the vector simuliid usually through larviciding (reviewed in WHO, 1995). Control in West Africa in latter years has been based mainly on parasite control, which has been found to be highly effective in most instances. In Brazil control using ivermectin has therefore been the method that is being used exclusively. Larviciding of the large lowland rivers in which $S$. oyapockense s.l. and S. roraimense breed (Figure 11) would be too costly and anyway is considered inappropriate in a hypoendemic area where the use of microfilaricides alone is suffi- cient (Shelley, 1991). Py-Daniel (1997) questioned the organization of the control program because of the semi-nomadic habits of the Yanomamis and also advocated the local control of S. guianense s.l., the most effective vector in highland areas, through the mechanical removal of vegetation on which they breed in the rivers. Local control of S. guianense s.l. by the method suggested is less likely to be effective because of the difficulty in locating their breeding grounds in localities where anthropophilic populations occur. At this stage the success of ivermectin as the only control tool in eliminating O. volvulus transmission is impossible to judge, given the lack of any broadranging monitoring program using vectors. It is probable that a combination of the habits of the Yanomami and the logistical difficulties in treatment will preclude a continual and high coverage treatment program. For these reasons resistance to the drug may occur and local vector control will possibly be necessary in addition to parasite control in the future in areas of hyperendemicity.

\section{Conclusions}

The major event affecting onchocerciasis in Brazil in recent years has been the decision to control the disease. Despite nine years of OEPA supervision of the control program, the epidemiology of onchocerciasis in the Amazonia focus of Brazil is not completely understood. This is due largely to the paucity of entomological data, which has precluded the setting up of an efficient control monitoring system. At the outset, health administrators at OEPA neglected to fully consult all local research groups and consequently the control program was initiated without a full knowledge of available scientific data. Py-Daniel (1997) questioned the basic organization of the control program in Brazil in terms of the sampling methods used for vectors and parasites based on work in Guatemala being inappropriate for Brazil. Consequently, control has been started in several localities where there were little or no baseline data on the simuliid fauna, vector species behavior, or infectivity rates with $O$. volvulus and other filariae, so that meaningful monitoring of the efficacy of control through ATPs was and still is not possible. Additionally, lack of funding has prevented the field application of a molecular technique (Morales-Hojas et al., 2001) already established in Fundação Oswaldo Cruz (FIOCRUZ) (but not the one advocated by OEPA) that can be used to distinguish both $O$. volvu- 
lus and the sympatric filaria M. ozzardi in infected vectors, a prerequisite for the rapid and accurate assessment of the ATPs for O. volvulus of vectors in control areas. The blinkered approach of Richards et al. (2000) to the investigation of dispersal of onchocerciasis from the Amazonia focus to other locations in Brazil and consequent lack of OEPA funding has also precluded the rapid assessment of whether dispersal of the disease to non-endemic areas is a significant threat in the future. Hence, no attempt has been made to sample the thousands of illegal miners in the focus who undoubtedly are contracting the disease and taking it elsewhere.

The situation may be redeemed once funding is made available to the FIOCRUZ team for entomological research and field application of their molecular technique to detect parasites in vectors, so that ATPs can be calculated for different locations in the Amazonia focus in order to monitor the control scheme. Funding should also be made available to determine the proportion of illegal miners infected in the Amazonia focus, their movements to other parts of Brazil, and the likelihood of new foci appearing. The serological and molecular techniques for screening miners are available in FIOCRUZ, and data for simuliid distribution in Brazil are held in FIOCRUZ and INPA (Instituto Nacional de Pesquisas na Amazônia). Other research projects of less immediate relevance to the control program are the incrimination of vectors of $M$. ozzardi and the role of vector cytospecies in
Figure 11

Breeding grounds of S. oyapockense s.I. and S. roraimense, primary vectors of onchocerciasis in lowland areas of the Amazonia onchocerciasis focus.

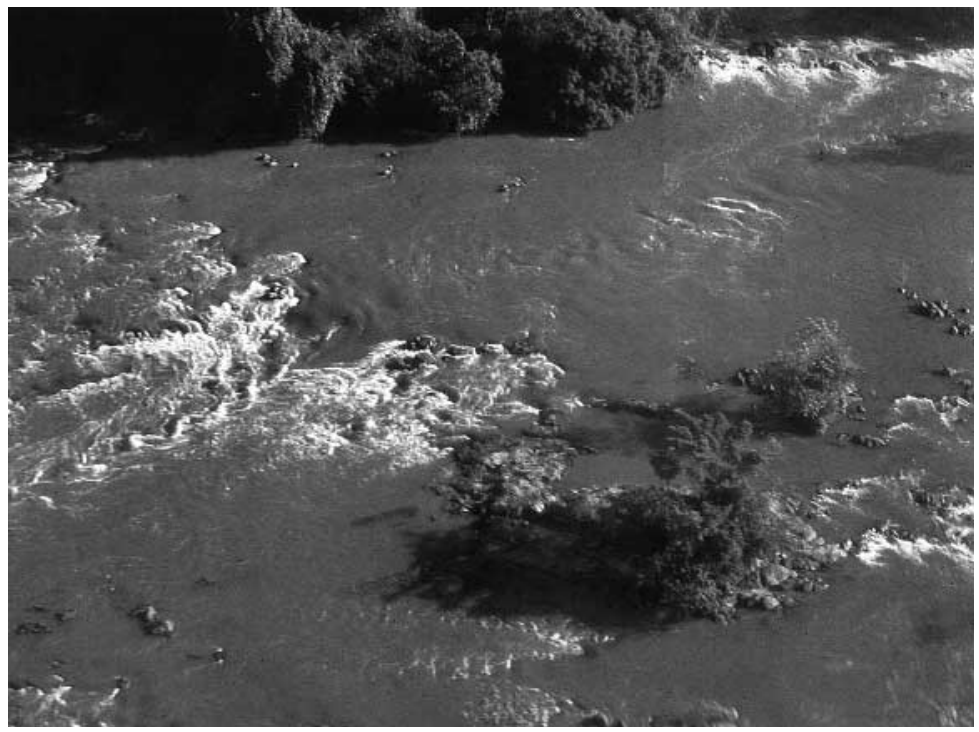

onchocerciasis transmission in the Amazonia focus, the production of a monograph on the biosystematics of the Simuliidae of Brazil, and completion of studies at the Minaçu focus to determine its extent and whether parasite transmission still occurs there.

\section{References}

ANDREAZZE, R. \& PY-DANIEL, V., 1999. Atividade hematofágica mensal e infecção natural de Psaroniocompsa incrustata (Lutz, 1910) (Diptera, Culicomorpha, Simuliidae) vetor de Onchocerca volvulus (Leuckart, 1893) em Xitei/Xidea, área indígena Yanomami, Roraima, Brasil. Entomología y Vectores, 6:415-440.

BEARZOTI, P.; LANE, E. \& MENEZES Jr., J., 1967. Relato de um caso de oncocercose adquirida no Brasil. Revista Paulista de Medicina, 70:102.

COELHO, G. E.; VIEIRA, J. B. F; GARCIA-ZAPATA, M. T. A. \& SCHUERTZ, J. C. M., 1998. Identificação de áreas de estratificação epidemiológica no foco de oncocercose na região Yanomami, Roraima, Brasil. Cadernos de Saúde Pública, 14:109-118.

CROSSKEY, R. W., 1990. The Natural History of Blackflies. Chichester: John Wiley \& Sons. 
FISCHER, P.; BUTTNER, D. W.; BAMUHIIGA, J. \& WILLIAMS, S. A., 1998. Detection of the filarial parasite Mansonella streptocerca in skin biopsies by a nested polymerase chain reaction-based assay. American Journal of Tropical Medicine \& Hygiene, 58:816-820.

GRILLET, M.-E.; BASAÑEZ, M.-G.; VIVAS-MARTINEZ, S.; VILLAMIZAR, N.; FRONTADO, H.; CORTEZ, J.; CORONEL, C. \& BOTTO, C., 2001. Human onchocerciasis in the Amazonian area of Southern Venezuela: Spatial and temporal variations in biting and parity rates of black fly (Diptera: Simuliidae) vectors. Journal of Medical Entomology, 38: 520-530.

LOWRY, C.; SHELLEY, T. \& TOWN, B., 1996. New focusing techniques characterise insects for the Natural History Museum in London. Laboratory News, October: A2-A3.

MAIA-HERZOG, M., 1999. A Oncocercose Humana no Brasil e sua Dispersão. Tese de Doutorado, Rio de Janeiro: Instituto Oswaldo Cruz, Fundação Oswaldo Cruz.

MAIA-HERZOG, M.; SHELLEY, A. J.; BRADLEY, J. E.; LUNA-DIAS, A. P. A.; CALVÃO, R. H. S.; LOWRY, C.; CAMARGO, M.; RUBIO, J. M.; POST, R. J. \& COELHO, G. E., 1999. Discovery of a new focus of human onchocerciasis in central Brazil. Transactions of the Royal Society of Tropical Medicine \& Hygiene, 93:235-239.

MAIA-HERZOG, M.; SHELLEY, A. J.; POST, R. J. \& BRADLEY, J. E., 2000. Monitoring for the emergence of new foci of onchocerciasis (river blindness) in the Americas - A reply. Transactions of the Royal Society of Tropical Medicine \& Hygiene, 94:108-109.

MEDEIROS, F. J. \& PY-DANIEL, V., 1999. Atividade hematofágica e infecção natural de três espécies de Simuliidae (Diptera: Culicomorpha) em Xitei/Xidea. Área indígena Yanomami, Roraima, Brasil. Entomología y Vectores, 6:210-226.

MORAES, M. A. P., 1991. Oncocercose entre os índios Yanomámi. Cadernos de Saúde Pública, 7:503-514.

MORAES, M. A. P.; SHELLEY, A. J.; CALHEIROS, L. B. \& PORTO, M. A. S., 1979. Estado atual do conhecimento sobre os focos brasileiros de oncocercose. Anais Brasileiros de Dermatologia, 54:73-85.

MORAES, M. A. P.; SHELLEY, A. J.; LUNA-DIAS, A. P. A. \& MANGABEIRA-SILVA, C. J., 1983. The concentration of Mansonella ozzardi microfilariae in skin capillaries. Transactions of the Royal Society of Tropical Medicine \& Hygiene, 77:463-466.

MORALES-HOJAS, R.; POST, R. J.; SHELLEY, A. J.; MAIA-HERZOG, M.; COSCARON, S. \& CHEKE, R. A., 2001. Characterisation of nuclear ribosomal DNA sequences from Onchocerca volvulus and Mansonella ozzardi (Nematoda: Filarioidea) and development of a new PCR-based method of detection in skin biopsies. International Journal for Parasitology, 31:169-177.

PY-DANIEL, V., 1983. Caracterização de dois novos subgeneros em Simuliidae (Diptera: Culicimorpha) Neotropical. Amazoniana, 8:159-223.

PY-DANIEL, V., 1997. Oncocercose, uma endemia focal no hemisfério norte da Amazônia. In: Homem, Ambiente e Ecologia no Estado de Roraima (R. I. Barbosa, E. J. G. Ferreira \& E. G. P. Castellón, org.), pp. 111-155, Manaus: Instituto Nacional de Pesquisas da Amazônia.

PY-DANIEL, V. \& MOREIRA-SAMPAIO, R. T., 1995. Gêneros e espécies de Simuliidae (Diptera: Culicimorpha) assinalados para o Brasil até 1995. Entomología y Vectores, 2:117-121.

RAMIREZ-PEREZ, J., 1983. Los Jejenes de Venezuela. Puerto Ayacucho: CAICET.

RAMIREZ-PEREZ, J.; YARZABAL, L. \& PETERSON, B., 1982. La Simuliofauna del Territorio Federal Amazonas (Venezuela). Publicación Científica 1. Caracas: Proicet Amazonas.

RICHARDS Jr., F;; CARTER, K.; CUPP, E.; SAUERBREY, M. \& KLEIN, R., 2000. Monitoring for the emergence of onchocerciasis (river blindness) in the Americas. Transactions of the Royal Society of Tropical Medicine \& Hygiene, 94:108.

SHELLEY, A. J., 1988. Vector aspects of the epidemiology of onchocerciasis in Latin America. Annual Review of Entomology, 33:337-366.

SHELLEY, A. J., 1991. Simuliidae and the transmission and control of human onchocerciasis in Latin America. Cadernos de Saúde Pública, 7:310-327.

SHELLEY, A. J., 1994. Factors affecting filarial transmission by simuliids. Advances in Disease Vector Research, 10:183-214.

SHELLEY, A. J.; LOWRY, C. A.; MAIA-HERZOG, M.; LUNA-DIAS, A. P. A. \& MORAES, M. A. P., 1997. Biosystematic studies on the Simuliidae (Diptera) of the Amazonia onchocerciasis focus of Brazil. Bulletin of the British Museum (Natural History) Entomology Series, 66:1-121.

SHELLEY, A. J.; MAIA-HERZOG, M. \& CALVÃO-BRITO, R., 2001a. The specificity of an ELISA for detection of Onchocerca volvulus in Brazil in an area endemic for Mansonella ozzardi. Transactions of the Royal Society of Tropical Medicine \& Hygiene, 95:1-3.

SHELLEY, A. J.; MAIA-HERZOG, M.; LOWRY, C. A.; LUNA-DIAS, A. P. A.; GARRITANO, P. R.; SHELLEY, A.; CAMARGO, M. \& CARTER, H. G., 2000. The Simuliidae (Diptera) of the secondary onchocerciasis focus at Minaçu in central Brazil. Bulletin of the British Museum (Natural History) - Entomology Series, 69:171-221.

SHELLEY, A. J.; MAIA-HERZOG, M.; LUNA-DIAS, A. P A.; CAMARGO, M.; COSTA, E. G.; GARRITANO, P R. \& LOWRY, C. A., 2001b. Biting behaviour and potential vector status of anthropophilic simuliid species (Diptera: Simuliidae) in a new focus of human onchocerciasis at Minaçu, central Brazil. Medical \& Veterinary Entomology, 15:1-12.

SHELLEY, A. J.; PINGER, R. R.; MORAES, M. A. P. \& HAYES, J., 1979. Concentration of microfilariae of Onchocerca volvulus by Simulium sanguineum during feeding: Use in mapping parasite distribution in the skin. Journal of Medical Entomology, 16:48-51.

VIVAS-MARTINEZ, S.; BASAÑEZ, M.-G.; BOTTO, C.; ROJAS, S.; GARCIA, M.; PACHECO, M. \& CURTIS, C. F., 2000a. Amazonian onchocerciasis: Parasitological profiles by host-age, sex, and endemicity in Southern Venezuela. Parasitology, 121:513-525.

VIVAS-MARTINEZ, S.; BASAÑEZ, M.-G.; BOTTO, C.; VILLEGAS, L.; GARCIA, M. \& CURTIS, C. F., 2000b. Parasitological indicators of onchocerciasis rele- 
vant to ivermectin control programmes in the Amazonian focus of Southern Venezuela. Parasitology, 121:527-534.

VIVAS-MARTINEZ, S.; BASAÑEZ, M. G.; GRILLET, M. E.; WEISS, H.; BOTTO, C.; GARCIA, M.; VILLAMIZARD, N. J. \& CHAVASSE, D. C., 1998. Onchocerciasis in the Amazonian focus of Southern Venezuela: Altitude and blackfly species composition as predictors of endemicity to select communities for ivermectin control programmes. Transactions of the Royal Society of Tropical Medicine and Hygiene, 92:613-620.

WHO (World Health Organization), 1995. Onchocerciasis and its Control. WHO Technical Report Series 852. Geneva: WHO.
YARZABAL, L.; BOTTO, C.; ARANGO, M.; RAGA, L. M.; WONG, F.; ALLAN, R.; JAIMES, I. L. \& SANCHEZBEAUJON, R., 1985. Epidemiological Aspects of Onchocerciasis in the Sierra Parima, Federal Territory of Amazonas, Venezuela. Publicación Científica 3. Puerto Ayacucho: CAICET.

ZIMMERMAN, P. A.; KATHOLI, C. R.; WOOTEN, M. C.; LANG-UNNASCH, N. \& UNNASCH, T. R., 1994. Recent evolutionary history of American Onchocerca volvulus, based on analysis of a tandemly repeated DNA sequence family. Molecular Biology and Evolution, 11:384-392.

Submitted on 25 April 2002

Approved on 23 May 2002 